ORIGINAL ARTICLE

\title{
Effect of Foeniculum Vulgare Aqueous and Alcoholic Seed Extract against Zoonotic Cutaneous Leishmaniasis
}

\author{
Gholamrezaei Mostafa $^{1}$, Jalallou Nahid ${ }^{1 *}$, Seyyedtabaei Seyyed javad ${ }^{2}$, Dadashi \\ Alireza $^{3}$, Salimi Sabour Ebrahim ${ }^{4}$
}

\section{OPEN ACCESS}

Citation: Gholamrezaei Mostafa, Jalallou Nahid, Seyyedtabaei Seyyed javad, Dadashi Alireza, Salimi Sabour Ebrahim. Aqueous and Alcoholic Seed Extract against Zoonotic Cutaneous Antileishmanial Activity of Foeniculum Vulgare Leishmaniasis. Ethiop J Health Sci.2021;31(2):408.doi:http://dx.doi.org/ 10.4314/ejhs.v31i2.23

Received: June 8, 2020

Accepted: July 8, 2020

Published: November 1, 2020

Copyright: (C) 2020 Jalallou N., et al. This is an open access article distributed under the terms of the Creative Commons Attribution License, which permits unrestricted use, distribution, and reproduction in any medium, provided the original author and source are credited.

Funding: AJA University of Medical Sciences

Competing Interests: The authors declare that this manuscript was approved by all authors in its form and that no competing interest exists.

Affiliation and Correspondence:

${ }^{1}$ Department of Medical

Laboratory Sciences, AJA

University of Medical Sciences,

Tehran, Iran.

${ }^{2}$ Department of Parasitology and Mycology, School of Medicine, Shahid Beheshti University of Medical Sciences, Tehran, Iran ${ }^{3}$ Department of Infectious Diseases, School of Medicine, AJA University of Medical Sciences, Tehran, Iran

4 Department of Pharmacognosy, School of Pharmacy, Shahid Beheshti medical sciences, Tehran, Iran

*Email: n.jalallou@ajaums.ac.ir

\section{ABSTRACT}

BACKGROUND: Cutaneous leishmaniasis is considered one of the major neglected tropical diseases. Drug resistance, limitary efficacy, and severe side effects remain a challenge for treatment. Foeniculum vulgare is known as a medicinal plant belonging to the Apiaceae, and anti-microbial properties of this plant have already been confirmed.

METHOD: The F.vulgare sterile aqueous and alcoholic extracts were prepared. In vitro has used $R A W 264.7$ cell line and $L$. major parasite (MRHO/IR/75/ER). Cytotoxicity assay on macrophages (CC50), cytotoxicity assay on promastigotes (IC50), and cytotoxicity assay on infected macrophages (EC50) were accomplished with both extracts by MTT and light microscopy methods. Four in vivo were allocated in four groups and five $B A L B / c$ mice each group. Stationary phase promastigotes were inoculated into the base of mice tails subcutaneously (SC). Measurement of the body weight, lesion size, parasite burden of the lesion, and spleen after 4 weeks for evaluation effects of the alcoholic extract on CL was done.

RESULTS: The results of in vitro revealed that the optimal concentrations of both extracts reducing the promastigotes and amastigotes growth. Alcoholic extract no harmful side effects for the host macrophages, while were indicated has a potent action against L. major. In vivo results after 4 weeks did not show any variation in lesion size and body weight. Also, lesion size and spleen parasite burden decreased in comparison to no treatment group.

CONCLUSION: The alcoholic extract could be a new alternative treatment for cutaneous leishmaniasis. However this extract needs more investigation for novel herbal drugs against CL.KEYWORDS: cutaneous leishmaniasis, Foeniculum vulgare seed extract, Leshimania, Major 


\section{INTRODUCTION}

Leishmaniasis is considered one of the six major neglected tropical diseases (NTDs) by the World Health Organization (WHO) (1). Currently, 13 million people in 98 countries have different types of leishmaniasis (2), and according to a 2017 report from the World Health Organization, about 600,000 to 1 million new cases each year have become a public health hazard worldwide (https://www.who.int/newsroom/fact-sheets/detail/leishmaniasis). The most common form of leishmaniasis is the cutaneous form caused by the protozoan parasites belonging to the genus Leishmania $(3,4)$. Drug resistance, limitary efficacy and severe side effects of common drugs such as sodium stibogluconate and meglumine antimoniate remain a challenge for treatment of cutaneous leishmaniasis (5). Therefore, these agents provide the need for a new effective antileishmanial drug.

Natural products and their compounds have long been used in the production of new drugs because they are cost-effective and easily accessible (6). Sweet fennel (Foeniculum vulgare) is known as a medicinal and aromatic plant belonging to the Apiaceae $(7,8)$. Antimicrobial properties of Foeniculum vulgare extract have been confirmed on bacteria and fungi $(9,10)$ so that it may affect the Leishmania parasite.

This is the first study that has been done on the anti-parasitic characteristics of $F$. vulgare aqueous and alcoholic seed extract against cutaneous leishmaniasis (CL) due to L. major. In in vivo, the most effective fennel extract, its cytotoxicity effects on promastigotes, macrophages and infected macrophages have been assessed. Lesion size and parasite burden of the spleen were measured in the infected $\mathrm{BALB} / \mathrm{c}$ mice.

\section{MATERIALS AND METHODS}

Preparation of plant extract: The $F$. vulgare seeds were obtained from the Barij Essence Pharmaceutical Company (Iran). Plant seeds were ground and macerated. Twenty-five grams of powder was solvated with $200 \mathrm{ml}$ methanol or distilled water and was shaken for 72 hours at $25^{\circ} \mathrm{C}$. After filtration through whatman filter paper (No. 4), re-extraction was carried out two times, and then the extracts of every sample were evaporated $\left(25^{\circ} \mathrm{C}\right)$ and dehydrated in desiccators under vacuum to a constant weight. At the end, products were sterilized entirely by filtration with a $0.22 \mu \mathrm{m}$ membrane filter. Finally, the alcoholic and aqueous extracts were applied in the project freshly.

Macrophage and parasite cultures: BALB/c mice-derived macrophage cell line RAW 264.7 (ATCC ${ }^{\circledR}$ TIB-71 ${ }^{\mathrm{TM}}$ ) (Iranian Biological Resource Center, Tehran, Iran) was cultured in High-glucose Dulbecco's Modified Eagle Medium (DMEM) (Bioidea, Iran) with 10\% Heat-inactivated Fetal Bovine Serum (FBS) (Gibco, USA) and 1\% Penicillin-streptomycin (pen/strep) $(10,000 \mathrm{U} / \mathrm{mL})$ (Gibco, USA). RAW 264.7 cells kept at $37^{\circ} \mathrm{C}$ in $5 \% \mathrm{CO} 2$ (pH 7.6). The passage of the RAW 264.7 cell line was accomplished by cell scraper after every 3 days. L. major promastigotes (MHROM/IR/75/ER) (Department of Parasitology, Tehran University of Medical Sciences, Tehran, Iran) cultured at 25 ${ }^{\circ} \mathrm{C}$ in RPMI 1640 (Biosera, France) supplemented with $10 \%$ FBS and $1 \%$ pen/strep. The passage of Leishmania parasite was done almost after 5 days according to medium color.

In-vitro cytotoxicity assay of the alcoholic and aqueous extracts on macrophages (CC50): In order to determine the cytotoxicity dosage of $F$. vulgare extract, the RAW 264.7 cells $\left(1 \times 10^{5}\right.$ cells) were seeded in the presence of the extract growing concentrations (10 to $4500 \mu \mathrm{g} / \mathrm{ml})$ in 96-well microliter culture plates in 5\% CO2 for $48 \mathrm{~h}$ at $37{ }^{\circ} \mathrm{C}$. Cell viabilities were measured using colorimetric 3-(4,5 dimethylthiazol-2-yl)2,5-diphenyl tetrazolium bromide (MTT) (Sigma-Aldrich, Deisenhofen, Germany) assay as it was described earlier (11). No treatment and glucantime ${ }^{\circledR}(5 \mathrm{mg} / \mathrm{mL})$ were used as controls. Absorbance ratios were measured at $530 \mathrm{~nm}$ wavelength. These results were indicated as the mean percentage $(\%)$ reduction of macrophages in comparison with untreated control samples $\times 100$. Finally, the concentration producing $50 \%(\mu \mathrm{g} / \mathrm{ml})(\mathrm{CC} 50)$ was determined with respect to the method performed by Weislow et al. (12). CC50 amounts were 
obtained using Prism 8 software (Graph-Pad Prism, San Diego, California, USA).

In-vitro cytotoxicity assay of the extracts on promastigotes (IC50): The effects of rising concentrations of $F$. vulgare extract (10 to 4500 $\mu \mathrm{g} / \mathrm{ml}$ ) on the stationary phase of $L$. major promastigotes $\left(1 \times 10^{6}\right.$ parasites $)$ were quantified for 48 hours at $26{ }^{\circ} \mathrm{C}$. The susceptibility was determined by counting with Neubauer chamber (13) and the extract concentration was estimated, which resulted in 50\% inhibition in promastigotes growth $(\mu \mathrm{g} / \mathrm{ml})$ (IC50).

In-vitro cytotoxicity assay of the extracts on infected macrophages by Leishmania (EC50): RAW 264.7 macrophages $\left(2 \times 10^{6}\right.$ cells $)$ were cultured onto a crystal chamber slide, along with in 24-well culture plate in DMEM medium supplemented with $10 \%$ FBS, which was incubated for 24 hours in $5 \% \mathrm{CO} 2$ at $37^{\circ} \mathrm{C}$. $L$. major promastigotes were cultured at $25^{\circ} \mathrm{C}$ in RPMI-1640 with 10\% FBS to reach stationary growth phase. Then, to infect RAW 264.7 macrophages, promastigotes were added to each chamber slide and 24-wells at the ratio of 1:10 with parasite- to-host, followed by incubation for 24 hours. Free promastigotes were removed by washing two times using serum-free RPMI1640 medium. Finally, infected macrophages were treated with increasing concentrations (10 to $4500 \mu \mathrm{g} / \mathrm{ml}$ ) of $F$. vulgare extract for 48 hours at $37{ }^{\circ} \mathrm{C}$ in $5 \% \mathrm{CO} 2$ as it was described earlier. After 48 hours, RPMI 1640 medium was removed and $50 \mu \mathrm{L}$ PBS was added. Then, it was scraped by scraper and transfered to slide. At the end of this stage, the slide was stained with Giemsa. The antileishmanial effect of the $F$. vulgare extract was assessed by microscopic method. Hundred macrophages were counted, and infected macrophage was reported as percent.

Selectivity Index (SI) Determination: Herein, the ratio of CC50 value of the cytotoxic activity to EC50 value of the antileishmanial activity was determined; then, the extract SI was calculated (14). Furthermore, SI of promastigotes was calculated (SI $=$ CC50 Macrophages/IC50 promastigote) (15). SI value under 10 shows ideal antileishmanial activity for this compound. Briefly, the ideal herbal compounds have the low cytotoxic, and they have the high antileishmanial activity (higher reported values $=$ greater extract activity) (14).

Ethical statements: All animal experimental procedures of this study were ratified by the Human and Animal Research Ethics Committee of Aja University of Medical Sciences (ethical code: IR. AJAUMS.MSP.REC1398.151). This study was done with respect to the guidelines of the Specific National Ethics for Biochemical Research issued by the Research and Technology Deputy of the Ministry of Health of Iran (issued in 2005).

Mice: All efforts were accomplished to decrease $\mathrm{BALB} / \mathrm{c}$ mice suffering throughout the experiment period. All the mice were female of $5 \pm 1$ week's old or $20 \mathrm{~g}$ weight that were purchased from Iran Pasteur Institute. Mice were placed in plastic cages and with free access to enough food and drinking water. BALB/c mice were kept in a controlled animal care facility including $21-25^{\circ} \mathrm{C}$, humidity $57 \pm 2 \%$, and 12 hours of light-dark cycles.

Parasite strain and mice infection: The Leishmania parasite was sustained in a high virulent state throughout a continuous passage in susceptible BALB/c mice. The spleen tissues from infected $\mathrm{BALB} / \mathrm{c}$ mice were squished and cultured at $26^{\circ} \mathrm{C}$ in RPMI 1640 medium supplemented with $10 \%$ FBS containing $1 \%$ pen/strep. All 20 laboratory mice were inoculated subcutaneously (SC) into the tail base, with Leishmania promastigotes $\left(2 \times 10^{6}\right)$ at liquid stationary phase culture. After thirty days, nodules and lesions emerged on 20 inoculated mice.

Treatment of infected mice with $F$. vulgare alcoholic extract: To test the $F$. vulgare extract effects on infected BALB/c mice, all mice were distributed into four separate groups: A, B, C, D, (five mice per each group). Group A was control group (received no treatment); group B received $F$. vulgare intralesionally (IL) according to in vitro $(300 \mu \mathrm{L} ; 4500 \mu \mathrm{g} / \mathrm{mL})$; group $\mathrm{C}$ received glucantime ${ }^{\circledR}$ intralesionally (IL) (injections of $20 \mathrm{mg} / \mathrm{kg}$ ); group D received PBS as placebo (three times per week for 4 weeks). 
Measurement of the lesion size and mice body weight: Size of the lesions and mice body weight was measured before and after 4 weeks of treatment using a metric caliper (Mitutoyo, Taiwan) and lab balance (Ohaus, Switzerland), respectively.

Quantification of Leishmania parasite load in lesion region: To measure the parasite load of the lesions, sampling was performed from the margins of lesions by using a vaccinostyle, and then smears were prepared. Smears on glass slides were fixed with absolute methanol, stained with Giemsa. Slides were evaluated for the presence of amastigotes using Zeiss light microscope (Carl Zeiss, Germany).

Quantification of Leishmania parasite load using limiting dilution assay (LDA): After eight weeks from infection, the Leishmania parasite load in the spleen was quantified by LDA. Furthermore, five mice from each group were scarified. Then, spleen was ground by 100 $\mu \mathrm{m}$ cell strainer and was transferred into the culture media;, amastigotes were transformed to the motile active promastigotes. Finally, motile RAW 264.7, F. vulgare alcoholic extract

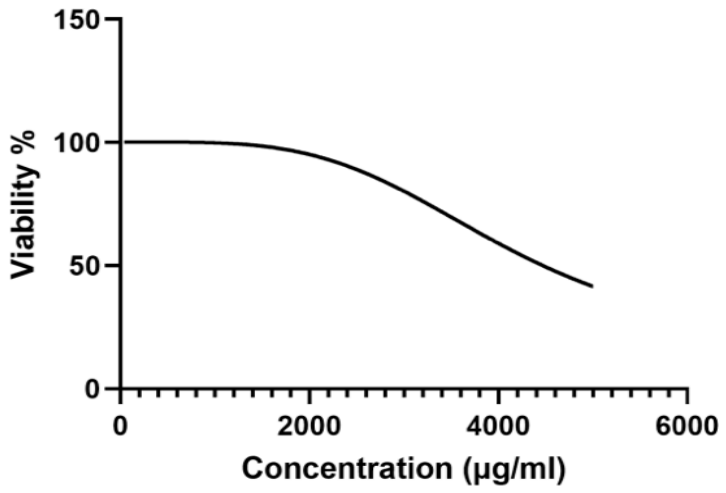

promastigotes were counted by invert microscopy and parasite load was assessed throughout, limiting dilution assay test as it was described earlier (16).

Statistical analysis: Statistical analyses of all cytotoxicity assays including CC50, EC50, and IC50 were performed by the use of Prism 8.0 software. Both one-way ANOVA and Student's t-test were used. Furthermore, statistical differences were supposed significant at $p$ values less than 0.05 . It is worth mentioning that all tests of our study were accomplished in duplicate.

\section{RESULTS}

Cytotoxicity effects of $F$. vulgare extracts on macrophages (CC50): As shown in Figure 1, $F$. vulgare extract was only toxic for RAW 264.7 macrophages at high extract concentrations. The CC50 $(\mu \mathrm{g} / \mathrm{ml})$ values of $F$. vulgare alcoholic and aqueous extracts at 48 hours were $4500 \mu \mathrm{g} / \mathrm{ml}$ and $3900 \mu \mathrm{g} / \mathrm{ml}$, respectively.

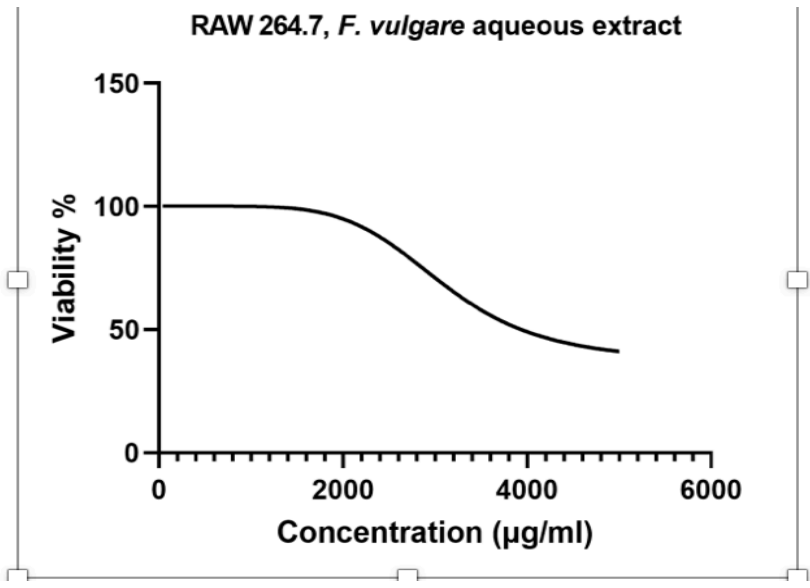

Figure 1: Cytotoxicity assay (CC50) of concentrations of F. vulgare alcoholic and aqueous extracts on mouse RAW 264.7 macrophage cell line after 48 hours using MTT method in vitro

Antileishmanial effects of $F$. vulgare extracts on Leishmania promastigotes (IC50): The $F$. vulgare alcoholic and aqueous extracts strongly inhibited the Leishmania parasite growth with the IC50 of $1200 \mu \mathrm{g} / \mathrm{ml}$ and $2500 \mu \mathrm{g} / \mathrm{ml}$ respectively at 48 hours (Figure 2).

Parasite Rescue and Transformation Assay (PRTA or transformed promastigotes) (EC50): As indicated in Figure 3, the $F$. vulgare alcoholic and aqueous extracts could inhibit the growth of Leishmania amastigotes, EC50 3900 $\mu \mathrm{g} / \mathrm{ml}$ and EC50 $4250 \mu \mathrm{g} / \mathrm{ml}$, respectively (Fig $3)$. Therefore, $F$. vulgare extract did not indicate any negative/toxic effects on mice RAW 264.7 macrophage cell line, but it could inhibit the intracellular amastigotes growth and kill the parasite (Figures 1 and 3). 

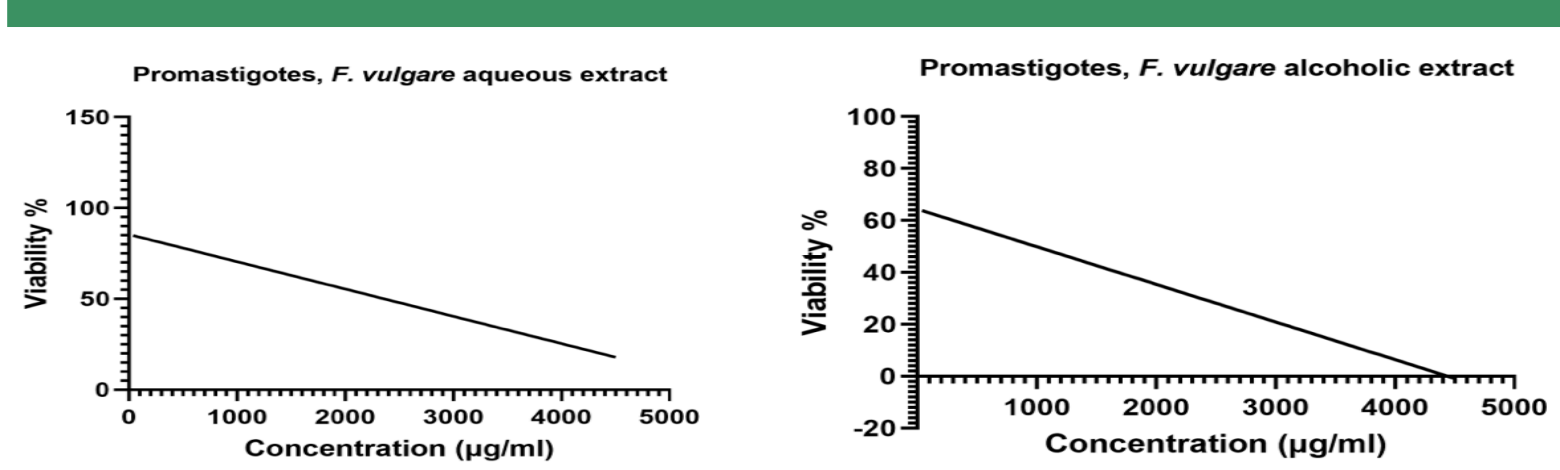

Figure 2. An inhibitory assay (IC50) of F. vulgare alcoholic and aqueous extracts concentrations on L. major promastigotes after 48 hours by using Neubauer chamber counting
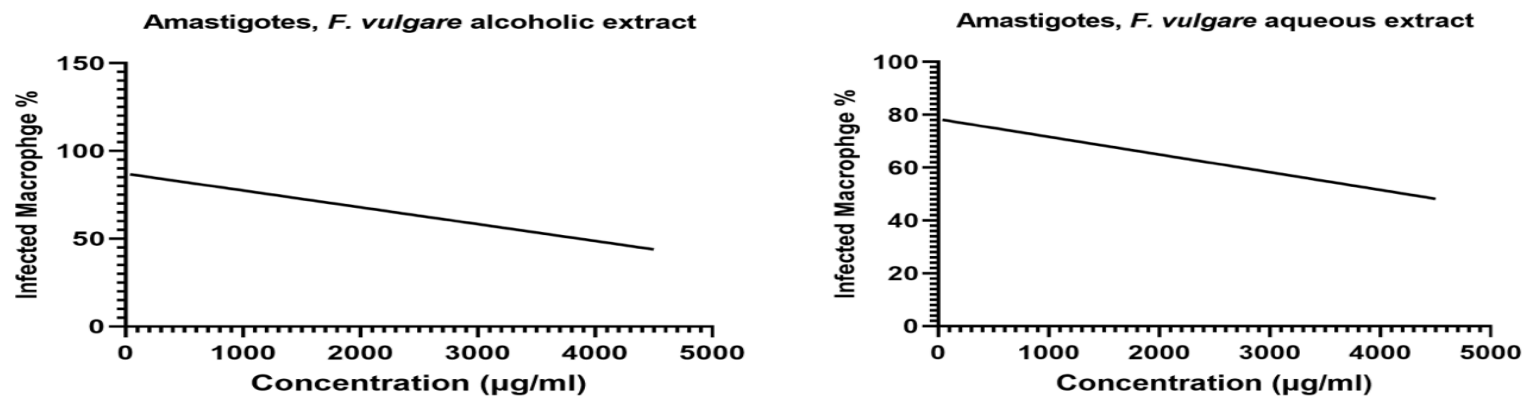

Figure 3:An effective concentration (EC50) of F. vulgare alcoholic and aqueous extracts L. major on L. major promastigotes after 48 hours by using light microscopy method

$F$. vulgare extracts and selectivity index (SI):

$F$. vulgare alcoholic and aqueous extracts were active against $L$. major amastigotes $(1.15 \mu \mathrm{g} / \mathrm{ml}$ and $0.9 \mu \mathrm{g} / \mathrm{ml}$, respectively) and promastigotes $(3.75 \mu \mathrm{g} / \mathrm{ml}$ and $1.56 \mu \mathrm{g} / \mathrm{ml}$, respectively) of $L$. major with a favorable SI compared to RAW 264.7 cell line macrophages. SI results were shown that alcoholic extract was more effective than aqueous extract.

Lesion size in infected BALB/c mice treatment with $F$. vulgare alcoholic extract: To measure the effect of $F$. vulgare alcoholic extract on the experimental CL development, $\mathrm{BALB} / \mathrm{c}$ mice were infected with stationary phase L. major. Afterwards, the development of CL lesion was monitored 8 weeks. Although CL lesions size in group $\mathrm{B}$ had not significant variation before and after treatment with $F$. vulgare alcoholic extract, it was reduced significantly as compared with $\mathrm{A}$ and $\mathrm{D}$ groups (Table 1) $(p<0.05)$. Even if body weight of $\mathrm{BALB} / \mathrm{c}$ mice in treated group with $F$. vulgare alcoholic extract (B group) had not considerable differences with prior treatment, body weight of this group increased significantly in comparison with the control group(A group) $(p<0.05)$ (Table 2).

Table 1: Variation of lesion size $\left(\mathrm{mm}^{2}\right)$ of infected BALB/c mice, before and after treatment

\begin{tabular}{lcccc}
\hline \multicolumn{1}{c}{ Groups } & $\begin{array}{c}\text { Before } \\
\text { treatment }\end{array}$ & $\begin{array}{c}\text { After 4 weeks } \\
\text { treatment }\end{array}$ & $\begin{array}{c}\boldsymbol{p} \text { value } \\
\text { (before/after) }\end{array}$ & $\begin{array}{c}\boldsymbol{p} \text { value (compare } \\
\text { to negative control) }\end{array}$ \\
\hline $\boldsymbol{F .}$ vulgare alcoholic extract & $13.4 \pm 3.8$ & $20 \pm 5.4$ & 0.065 & $<0.0001$ \\
PBS (vehicle) & $14.3 \pm 3.7$ & $37.3 \pm 8.9$ & $<0.0001$ & 0.081 \\
Glucantime ${ }^{8}$ & $12.4 \pm 2.3$ & $9.1 \pm 2.1$ & 0.356 & $<0.0001$ \\
Negative Control & $15.1 \pm 2.8$ & $43.6 \pm 9.2$ & $<0.0001$ & ----- \\
\hline
\end{tabular}

Values are represented as mean \pm SD, Positive control (Glucantime $\left.{ }^{\circledR}\right)$ : the mice were treated twice a week till four weeks with $300 \mu \mathrm{l}(5 \mathrm{mg} / \mathrm{ml})$ intralesional injection. $(p<0.05)$

DOI: http://dx.doi.org/10.4314/ejhs.v31i2.23 
Table 2. Variation of body weight (gr) of infected BALB/c mice, before and after treatment

\begin{tabular}{lcccc}
\hline \multicolumn{1}{c}{ Groups } & $\begin{array}{c}\text { Before } \\
\text { treatment }\end{array}$ & $\begin{array}{c}\text { After 4 weeks } \\
\text { treatment }\end{array}$ & $\begin{array}{c}\boldsymbol{p} \text { value } \\
\text { (before/after) }\end{array}$ & $\begin{array}{c}\boldsymbol{p} \text { value (compare } \\
\text { to negative control) }\end{array}$ \\
\hline $\boldsymbol{F}$. vulgare alcoholic extract & $17.0 \pm 1.0$ & $17.1 \pm 1.0$ & 0.950 & 0.049 \\
PBS (vehicle) & $16.9 \pm 1.3$ & $16.3 \pm 0.7$ & 0.368 & 0.082 \\
Glucantime® & $15.9 \pm 0.8$ & $15.4 \pm 0.4$ & 0.513 & 0.827 \\
Negative Control & $16.8 \pm 1.3$ & $15.7 \pm 0.7$ & 0.111 & ----- \\
\hline
\end{tabular}

Values are represented as mean $\pm \mathrm{SD}$, Positive control (Glucantime $\left.{ }^{\circledR}\right)$ : the mice were treated twice a week till four weeks with $300 \mu \mathrm{l}(5 \mathrm{mg} / \mathrm{ml})$ intralesional injection $(p<0.05)$.

Parasite burden in lesion and spleen of infected BALB/c mice: $F$. vulgare alcoholic extract reduced significantly parasite burden in $\mathrm{BALB} / \mathrm{c}$ mice lesions in comparison to no treatment group $(p<0.05)$. Four weeks after treatment, the L. major burden in the draining spleen of $B A L B / c$ mice was evaluated using limiting dilution assay (LDA). The L. major parasite burden was significantly reduced in $F$. vulgare alcoholic extract group compared to no treatment and PBS groups (Figure 4$)(p<0.05)$.

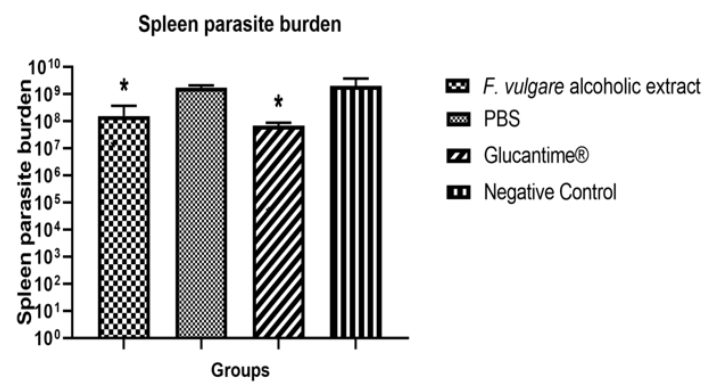

Fig 4. Spleen parasite burden in infected BALB/c mice after 4 weeks by using LDA $(p<0.05)$.

\section{DISCUSSION}

Traditionally, attempts have been made to use herbal plants to treat cutaneous leishmaniasis (17). As previously mentioned, resistance to chemical drugs and their side effects have been reported in the treatment of cutaneous leishmaniasis (5). Herbal useful remedies could be used to replace chemical treatments for cutaneous leishmaniasis treatment (18). $F$. vulgare, belonging to the Umbelliferae (Apiaceae) family, is a plant native to the Mediterranean area. Fennel are cultivated in different regions of Europe and Asia, and most of them are imported from India, China and Egypt (19-21). Various studies have reported on the effect of this plant extract on genital system, respiratory disorders and digestive system $(22,23) . F$. vulgare is known as anti-microbial, anti-inflammatory, anti-diabetic, anti-tumor, with low toxicity and has immunomodulatory effect $(9,22,24,25)$. This study showed the therapeutic effects of aqueous and alcoholic extracts of $F$. vulgare as herbal drug without extreme toxicity to host cells. Determination of anti-leishmanial activity of $F$. vulgare extracts were accomplished with IC50, CC50 and EC50. The results of this research revealed that the optimal concentrations of the alcoholic extract for reducing the promastigotes and amastigotes growth were 1200 and $3900 \mu \mathrm{g} / \mathrm{ml}$, respectively. According to this study, $F$. vulgare alcoholic extract has a potent action against L. major promastigotes and amastigotes whereas it doesn't have any harmful side effect on the host macrophages. Two main components including bis (2-ethylhexyl) phthalate and trans-anethole, are predominantly responsible for most of antileishmanial effects (26). Kataoka et al. showed that the fennel extract could inhibit inflammatory event (27). The suppressive effects of methanol extract against acute and subacute sickness, type 4 allergic reactions through cyclooxygenase and lipoxygenase inhibition have already been confirmed (28). There are active compounds with anti-microbial activity such as oleic acid and coumarin in aqueous and alcoholic extracts $(29,30)$. The prenylated coumarins auraptene, galbanic acid and umbelliprenin isolated from another genus Apiaceae (Ferula szowitsiana) were revealed invitro antileishmanial effects on $L$. major promastigotes in comparison with the negative control $(31,32,33)$. The SI was known as a major index of herbal extract activity that is used in order to describe a compound's in vitro 
efficacy in the parasite proliferation inhibition (15). This index revealed that the $F$. vulgare alcoholic extract was more toxic to L. major parasite in comparison with the macrophages. Indeed, the alcoholic extract indicated a remarkable anti-leishmanial activity, and has the potency to decrease the survival rate of amastigotes at nontoxic concentrations for the host cell. After treatment of infected BALB/c mice with $F$. vulgare alcoholic extract, all of the treatment groups did not show any increase in lesions size in comparison with no treatment and PBS groups. The LDA and light microscopy method demonstrated a considerable difference between the parasite burden in the $F$. vulgare extract and a glucantime ${ }^{\circledR}$ treated groups, in comparison with PBS and no treatment. Also, a significant increase in body weight of $F$. vulgare alcoholic extract treated mice showed that this extract had no toxic side effects on mice growth. In this study, methanolic extract is more effective than aqueous extract to killing Leishmania parasite but toxic for mammalian cells. As shown in Hamdy Roby and et al study, using other solvent such as hexane and diethyl ether can be found having better result against Leishmania major (10). Many studies have been conducted on effective drugs in order to decrease infection by parasites. Some research has been done on the use of herbal drugs on $L$. major parasites. Various types of drug delivery and nanoparticle therapy were examined in order to determine the effectiveness of herbal materials and disease treatments by pharmaceutical companies. In Iran, different types of herbal extracts have been considered for treating the L. major infection. Previously, no evidences reported on the anti-leishmanial effects of $F$. vulgare alcoholic extract in a mice model. This herbal extract could be a new alternative treatment for cutaneous leishmaniasis. Therefore, $F$. vulgare alcoholic extract with more investigation could be a candidate for novel herbal drugs against neglected tropical diseases such as leishmaniasis, and its promising effects for future studies is considerable.

\section{REFERENCES}

1. Hotez PJ, Savioli L, Fenwick A. Neglected tropical diseases of the Middle East and North Africa: review of their prevalence, distribution, and opportunities for control. PLoS Negl Trop Dis 2012; 6(2): e1475.

2. Karimkhani C, Wanga V, Coffeng LE, Naghavi P, Dellavalle RP, Naghavi M. Global burden of cutaneous leishmaniasis: a cross-sectional analysis from the Global Burden of Disease Study 2013. Lancet Infect Dis 2016; 16(5): 58491.

3. Sabzevari S, Mohebali M, Hashemi SA. Mucosal and mucocutaneous leishmaniasis in iran from 1968 to 2018: A narrative review of clinical features, treatments, and outcomes. Int $J$ Dermatol 2020; 59(5): 606-12.

4. Khanjani N, González U, Leonardi-Bee J, Khamesipour A. A meta-analysis of vaccines for preventing cutaneous leishmaniasis. $J$ Vaccines Vaccin Stud 2020; 1(1): 101.

5. Croft SL, Sundar S, Fairlamb AH. Drug resistance in leishmaniasis. Clin Microbiol Rev 2006; 19(1): 11-26

6. Rocha LG, Almeida JR, Macedo RO, BarbosaFilho JM. A review of natural products with antileishmanial activity. Phytomedicine 2005; 12(6-7): 514-35.

7. Choi EM, Hwang JK. Anti-inflammatory, analgesic and antioxidant activities of the fruit of Foeniculum vulgare. Fitoterapia 2004; 75(6): 557-65.

8. Telci I, Demirtas I, Sahin A. Variation in plant properties and essential oil composition of sweet fennel (Foeniculum vulgare Mill.) fruits during stages of maturity. Ind Crops Prod 2009; 30(1): 126-30.

9. Kwon YS, Choi WG, Kim WJ, cKim WK, Kim MJ, Kang WH et al. Antimicrobial Constituents of Foeniculum vulgare. Arch Pharm Res 2002; 25: $154-57$.

10. Hamdy Roby MH, Sarhan MA, Selim KAH, Khalel KI. Antioxidant and antimicrobial activities of essential oil and extracts of fennel (Foeniculum vulgare L.) and chamomile (Matricaria chamomilla L.). Ind Crops Prod 2013; 44: 437-45.

11. Dutta A, Bandyopadhyay S, Mandal C, Chatterjee M. Development of a modified MTT assay for screening antimonial resistant field isolates of Indian visceral leishmaniasis. Parasitol Int 2005; 54(2): 119-22.

12. Weislow OS, Kiser R, Fine DL, Bader J, Shoemaker RH, Boyd MR. New solubleformazan assay for HIV-1 cytopathic effects:

DOI: http://dx.doi.org/10.4314/ejhs.v31i2.23 
application to high-flux screening of synthetic and natural products for AIDS-antiviral activity. J Natl Cancer Inst 1989; 81(8): 577-86.

13. Moein MR, Hatam G, Taghavi-Moghadam R, Zarshenas MM. Antileishmanial Activities of Greek Juniper (Juniperus excelsa M.Bieb.) Against Leishmania major Promastigotes. J Evid Based Complementary Altern Med 2017; 22(1): 31-36.

14. Lehnhardt Pires C, Rodrigues S, Bristot D, Gaeta H, de Oliveira Toyama D, Lobo Farias W, et al. Evaluation of macroalgae sulfated polysaccharides on the Leishmania (L.) amazonensis promastigote. Mar Drugs 2013; 11(3): 934-43.

15. Ramı'rez-Maci'as I, Maldonado CR, Marı'n C, Olmo F, Gutie'rrez-Sa'nchez R, Rosales MJ, et al. In vitro anti-leishmania evaluation of nickel complexes with a triazolopyrimidine derivative against Leishmania infantum and Leishmania braziliensis. J Inorg Biochem 2012; 112; 1-9.

16. Titus RG, Marchand M, Boon T, Louis J. A limiting dilution assay for quantifying Leishmania major in tissues of infected mice. Parasite Immunol 1985; 7(5): 545-55.

17. Bahmani M, Saki K, Ezatpour B, Shahsavari S, Eftekhari Z, Jelodari M, et al. Leishmaniosis phytotherapy: Review of plants used in Iranian traditional medicine on leishmaniasis. Asian Pac J Trop Biomed 2015; 5(9): 695-701.

18. Tiuman TS, O Santos A, Ueda-Nakamura T, P Dias Filho B, V Nakamura C. Recent advances in leishmaniasis treatment. Int J Infect Dis 2011; 15(8): e525-32.

19. Badgujar SB, Patel VV, Bandivdekar AH. Foeniculum vulgare Mill: A Review of Its Botany, Phytochemistry, Pharmacology, Contemporary Application, and Toxicology. Biomed Res Int 2014; 2014: 842674.

20. Senatore F, Oliviero F, Scandolera E, Taglialatela-Scafati O, Roscigno G, Zaccardelli $\mathrm{M}$, et al. Chemical composition, antimicrobial and antioxidant activities of anethole-rich oil from leaves of selected varieties of fennel [Foeniculum vulgare Mill. ssp. vulgare var. azoricum (Mill.) Thell]. Fitoterapia 2013; 90: 214-9.

21. Namavar JB, Tartifizadeh A, Khabnadideh S. Comparison of fennel and mefenamic acid for the treatment of primary dysmenorrhea. Int $J$ Gynaecol Obstet 2003; 80: 153-7.

22. Khazaei M, Montaseri A, Khazaei MR, Khanahmadi M. Study of Foeniculum vulgare effect on folliculogenesis in female mice. Int $J$ Fertil Steril 2011; 5: 122-7.
23. Ostad SN, Soodi M, Shariffzadeh M, Khorshidi N, Marzban H. The effect of fennel essential oil on uterine contraction as a model for dysmenorrhea, pharmacology and toxicology study. J Ethnopharmacol 2001; 76(3): 299-304.

24. Albert-Puleo M. Fennel and anise as estrogenicagents. J Ethnopharmacol 1980 ; 2(4): $337-44$

25. Naeini AR, Khosravi AR, Tajbakhsh H, Ghazanfari T, Yaraee R. Anticandida and Immunomodulatory Effects of Foeniculum Vulgare Mill in vitro. Daneshvar Medicine 2009; 16(82); 7- 20. [In Persian]

26. Ekhtelat M, Arzani Birghani S, Namjoyan F, Ameri A. The antibacterial activity of barberry root and fennel seed extracts individually and in combination with nisin and sodium diacetate against Escherichia coli O157:H7. Jundishapur J Nat Pharm Prod 2020; 15(1): e55078.

27. Kataoka H, Horiyama S, Yamaki M, Oku H, Ishiguro $\mathrm{K}$, Katagi $\mathrm{T}$, et al. Anti-inflammatory and anti-allergic activities of hydroxylamine and related compounds. Biol Pharm Bull 2002; 25(11): 1436-41.

28. Kooti W, Moradi M, Ali-Akbari S, SharafiAhvazi N, Asadi-Samani M, Ashtary-Larky D. Therapeutic and pharmacological potential of Foeniculum vulgare Mill: a review. J HerbMed Pharmacol 2015; 4(1): 1-9.

29. Pinheiro IM, Carvalho IP, de Carvalho CE, Brito LM, da Silva ABS, Conde Júnior AM, et al. Evaluation of the in vivo leishmanicidal activity of amphotericin B emulgel: An alternative for the treatment of skin leishmaniasis. Exp Parasitol 2016; 164: 49-55.

30. Napolitano HB, Silva M, Ellena J, Rodrigues BDG, Almeida ALC, Vieira PC, et al. Aurapten, a coumarin with growth inhibition against Leishmania major promastigotes. Braz J Med Biol Res 2004; 37(12): 1847-52.

31. Mahiou V, Roblot F, Hocquemiller R, Cave A, Angelo A, Fournet A, et al. Opportunity, challenge and scope of natural products in medicinal chemistry. Nat Prod 1995; 58: 324.

32. Muzitano MF, Tinoco LW, Guette C, Kaiser CR, Rossi-Bergmann B, Costa SS. The antileishmanial activity assessment of unusual flavonoids from Kalanchoe Pinnata. Phytochemistry 2006; 67(18): 2071-7.

33. Roberto da Silva E, do Carmo Maquiaveli C, Magalhaes PP. The leishmanicidal flavonols Quercetin and Quercitrin target Leishmania (Leishmania) amazonensis Arginase. Exp Parasitol 2012; 130(3): 183-8. 